\title{
Benign Atypical Intralymphatic CD30+ T-Cell Proliferation: A Case Report and Literature Review
}

\author{
$\mathrm{Nu}$ Ri Jang, Min Kyoung Kim ${ }^{1}$ Dong Hoon Shin², Mi Jin Gu \\ Departments of Pathology, ${ }^{1}$ Internal Medicine, and ${ }^{2}$ Dermatology, Yeungnam University College of Medicine, Daegu, Korea
}

\section{Dear Editor:}

The presence of atypical large lymphoid cells within vascular spaces is an uncommon finding in the skin and suggests intravascular lymphoma $(\mathrm{IVL})^{1}$. We present a rare case of benign atypical intralymphatic CD30 + T-cell proliferation, that mimicked IVL, along with a review of the literature. A 69-year-old man presented with confusion. Magnetic resonance imaging identified a $2.5 \mathrm{~cm}$ mass in left temporoparietal lobe of brain. He was diagnosed with primary diffuse large B-cell lymphoma (DLBL) of the central nerve system (CNS) and underwent chemotherapy with methotrexate and cytarabine. On the second day of chemotherapy, a 0.7 well demarcated ulcer was found on the penile shaft and a punch biopsy was performed (Fig. 1A). Microscopically, the epidermis showed ulceration and superficial dermis contained thin-walled dilated lymphatic vessels, some of which were filled with atypical lymphoid cells (Fig. 2A). The lymphoid cells were medium-to-large with pleomorphic nuclei with prominent small nucleoli (Fig. 2B). These cells were positive for CD3 (Fig. 2C) and CD30 (Fig. 2D), but negative for CD20, CD56, and anaplastic lymphoma kinase (ALK). Epstein-

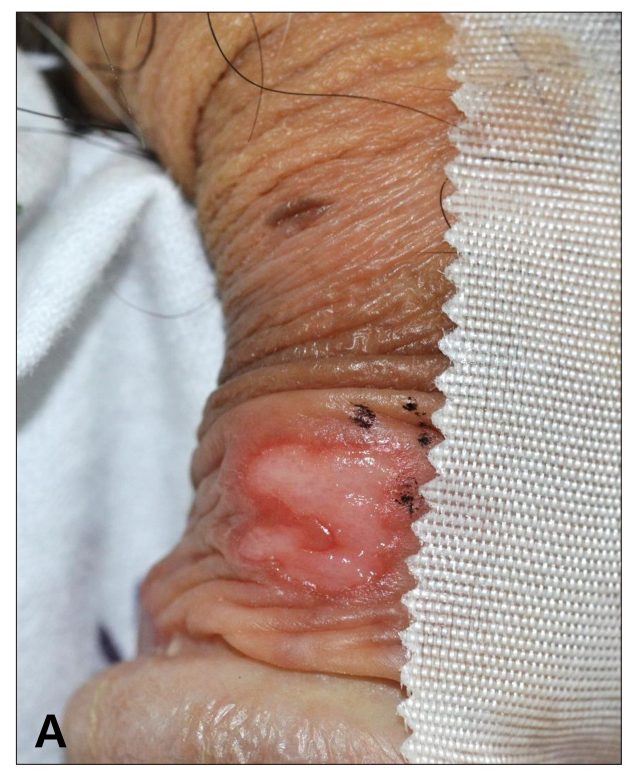

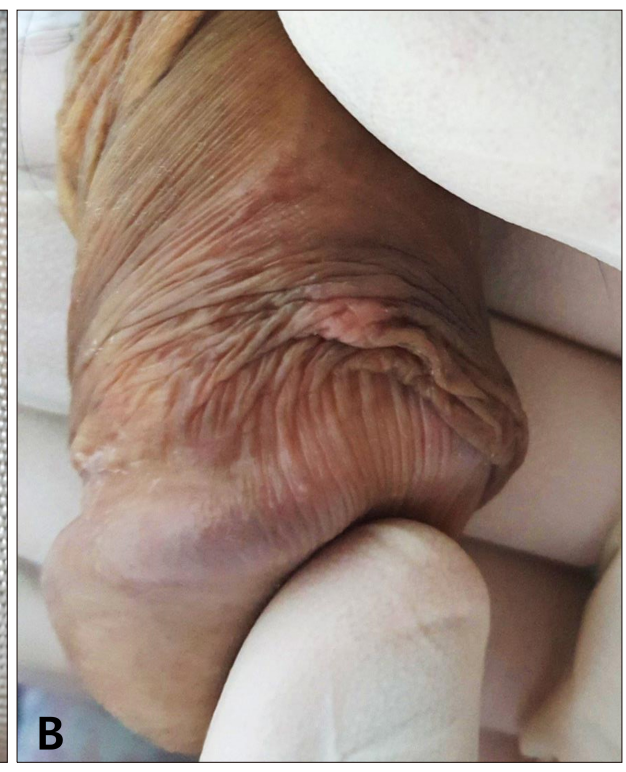

Fig. 1. (A) A well demarcated ulcer was on penile shaft. (B) Two month later, the lesion was regressed without any treatment.

\section{Received December 16, 2017, Revised January 19, 2018, Accepted for publication February 9, 2018}

Corresponding author: Mi Jin Gu, Department of Pathology, Yeungnam University College of Medicine, 170 Hyeonchung-ro, Nam-gu, Daegu 42415, Korea. Tel: 82-53-640-6756, Fax: 82-53-622-8432, E-mail: mjgu@yu.ac.kr ORCID: https://orcid.org/0000-0002-8350-3038

This is an Open Access article distributed under the terms of the Creative Commons Attribution Non-Commercial License (http://creativecommons.org/ licenses/by-nc/4.0) which permits unrestricted non-commercial use, distribution, and reproduction in any medium, provided the original work is properly cited.

Copyright (C) The Korean Dermatological Association and The Korean Society for Investigative Dermatology 


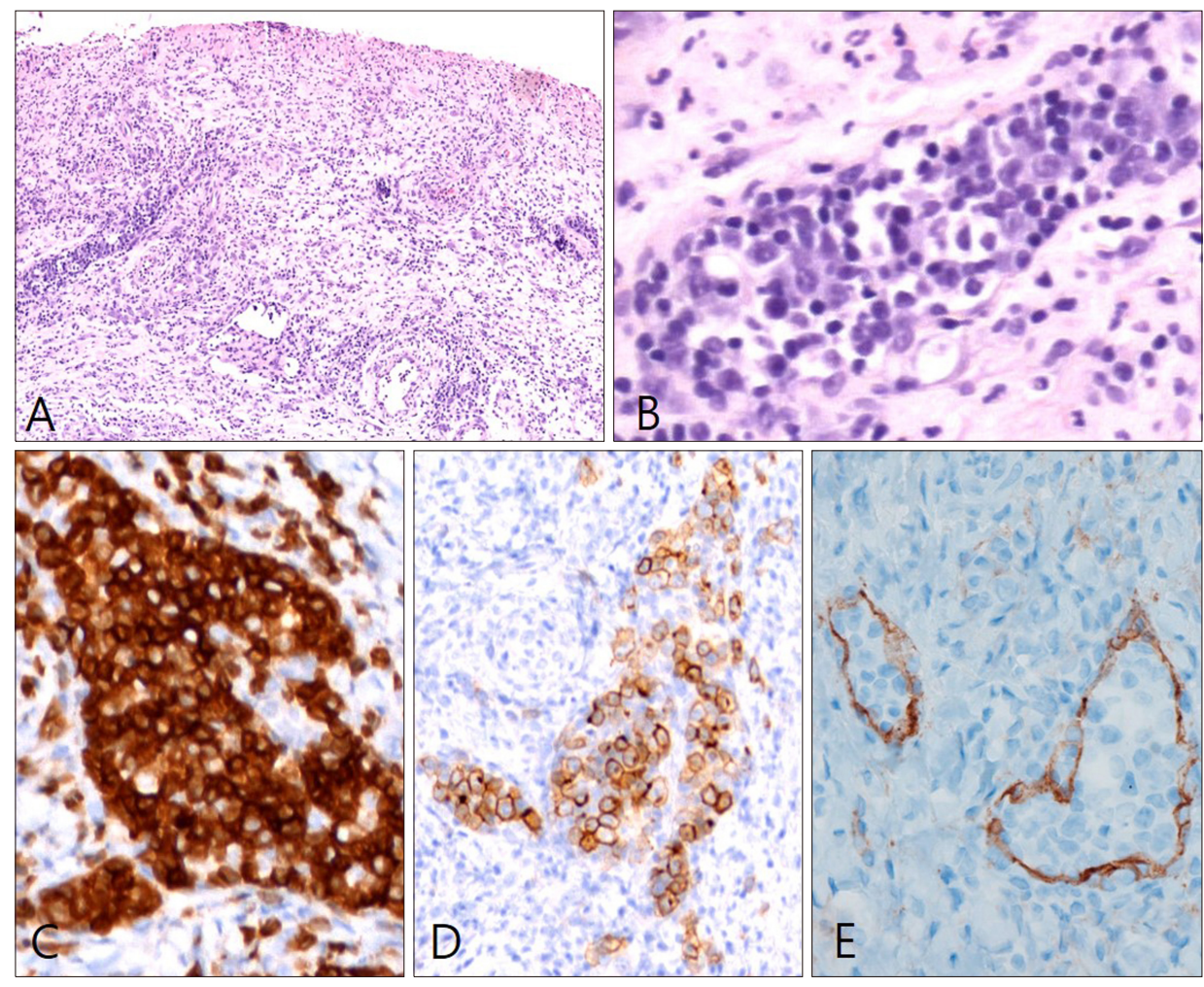

Fig. 2. (A) The epidermis showed ulceration and superficial dermis contained thin-walled dilated lymphatic vessels with atypical lymphoid cells $(H \& E, \times 4)$. (B) Intralymphatic atypical lymphoid cells infiltration $(H \& E, \times 200)$. The atypical cells express CD3 $(C, \times 400)$ and CD30 (D, $\times 400)$. The lymphatic spaces are highlighted by D2-40 (E, $\times 400$ ).
Barr virus-encoded small RNA (EBER) in situ hybridization test was negative, and a BIOMED-2 T-cell receptor gamma gene clonality assays showed polyclonality. The lesion spontaneously regressed without any treatment after two months (Fig. 1B). We received the patient's consent form about publishing all photographic materials.

The presence of atypical lymphoid cells in vascular space suggests possible IVL. Most IVLs are of the B-cell lineage with an aggressive clinical course, and are commonly represented by DLBL and predominant intravascular growth ${ }^{2}$. Recently, there have been several reports of cutaneous intravascular $\mathrm{CD} 30+\mathrm{T}$-cell lymphoproliferative disease (CD30 + TLPD); anaplastic large cell lymphoma (ALCL) and lymphomatoid papulosis (LyP)-like TLPD ${ }^{3,4}$. Furthermore, benign proliferation of intralymphatic atypical CD30+ T-cells has also been reported ${ }^{1,5}$. Irrespective of diagnostic diversity, intralymphatic ALCL, LyP-like TLPD, and benign atypical $\mathrm{CD} 30+$ T-cell proliferation exhibit compatible morphologic/immunophenotypic features and a similar clinical course (Supplementary Table 1).

Intravascular $\mathrm{ALCL}$ presents as a single or multiple nodules and plaques $(1.2 \sim 12 \mathrm{~cm})^{3,4}$. Tumor expresses CD30, but is negative for cytotoxic markers, ALK, and EBER ${ }^{1}$. Lymphomatoid papulosis-like TLPD present multiple plaques and patches that wax and wane $\mathrm{s}^{3}$. To date, only 10 cases of benign atypical intravascular CD30 + T-cell lymphoid proliferation have been reported ${ }^{1,5}$. Patients age range from 17 77 years and the lesions occur on the extremities, trunk, neck, eyelid, left inguinal, uterus polyp and prepuce. Nine cases presented as single lesion $(1 \sim 3$ $\mathrm{cm})$, while one presented as multiple lesions with drug rash. No cases showed clinical signs of lymphoma or clonality ${ }^{1}$. Nine cases showed complete remission without recurrence after excision or biopsy ${ }^{1}$ while one underwent radiotherapy that lead to complete remission ${ }^{5}$.

Although this patient received chemotherapy for the primary CNS DLBL, but the lymphoma continued to progress. After switching to radiotherapy, the lymphoma decreased. The penile lesion regressed with no recurrence in the last 7 months.

In conclusion, we report a rare case of benign atypical intralymphatic CD30 + T-cell proliferation that mimicked IVL. Pathologist and dermatologist should be aware of this entity and its clinical features to avoid misinterpretation.

\section{SUPPLEMENTARY MATERIALS}

Supplementary data can be found via http://anndermatol. org/src/sm/ad-31-108-s001.pdf.

\section{CONFLICT OF INTEREST}

The authors have nothing to disclose. 


\section{ORCID}

Nu Ri Jang, https://orcid.org/0000-0001-7182-964X

Min Kyoung Kim, https://orcid.org/0000-0003-0088-0995

Dong Hoon Shin, https://orcid.org/0000-0003-3130-3699

Mi Jin Gu, https://orcid.org/0000-0002-8350-3038

\section{REFERENCES}

1. Kempf W, Keller K, John H, Dommann-Scherrer C. Benign atypical intravascular CD30 + T-cell proliferation: a recently described reactive lymphoproliferative process and simulator of intravascular lymphoma: report of a case associated with lichen sclerosus and review of the literature. Am J Clin Pathol 2014;142:694-699.
2. Riveiro-Falkenbach E, Fernández-Figueras MT, RodríguezPeralto JL. Benign atypical intravascular CD30(+) T-cell proliferation: a reactive condition mimicking intravascular lymphoma. Am J Dermatopathol 2013;35:143-150.

3. Samols MA, Su A, Ra S, Cappel MA, Louissant A Jr, Knudson RA, et al. Intralymphatic cutaneous anaplastic large cell lymphoma/lymphomatoid papulosis: expanding the spectrum of CD30-positive lymphoproliferative disorders. Am J Surg Pathol 2014;38:1203-1211.

4. Nguyen $\mathrm{GH}$, Yassin AH, Magro CM. Unusual variants of intravascular malignant hematopoietic neoplasms: a report of 4 cases and review of the literature. Am J Dermatopathol 2015;37:360-367.

5. Calamaro P, Cerroni L. Intralymphatic proliferation of T-cell lymphoid blasts in the setting of hidradenitis suppurativa. Am J Dermatopathol 2016;38:536-540.

\title{
Fibroma of Tendon Sheath Mimicking a Corn - a Rare Hand Tumor
}

\author{
Hee Jae Park, Seung Pil Ham, Cheong Ha Woo, Mira Choi, Hai-Jin Park \\ Department of Dermatology, Ilsan Paik Hospital, Inje University College of Medicine, Goyang, Korea
}

\section{Dear Editor:}

Fibroma of tendon sheath (FTS) is an uncommon soft tissue neoplasm belonging to the benign fibroblastic/myofibroblastic tumor group. It is manifested as an asymptomatic, firm, and well-demarcated nodule that grows slowly. FTS has a predilection to adhere to the tendon or tendon sheath of digits and palms, especially on the flexor surface ${ }^{1}$.

A 21-year-old man visited our department with a 2-month history of a solid mass on the volar aspect of his left thumb (Fig. 1). Physical examination revealed a hard hy- perkeratotic papule, smaller than $1 \mathrm{~cm}$. He reported mild tenderness without limitation in the range of motion. There was no history of trauma, but the lesion was trimmed at the local clinic due to suspicion of corn. To confirm a diagnosis, an incisional biopsy was performed. The specimen showed a well-circumscribed tumor in the deep dermis comprised of hyalinized collagenous fibers with haphazardly arrayed spindle-shaped cells and slit-like vascular spaces. The cells were immunoreactive for smooth muscle actin (SMA) and the fibrotic regions appeared blue in Masson's trichrome staining (Fig. 2). Based on the clin-

\footnotetext{
Received January 12, 2018, Revised February 8, 2018, Accepted for publication February 12, 2018
}

Corresponding author: Hai-Jin Park, Department of Dermatology, Ilsan Paik Hospital, Inje University College of Medicine, 170 Juhwa-ro, Ilsanseo-gu, Goyang 10380, Korea. Tel: 82-31-910-7224, Fax: 82-31-910-7227, E-mail: stratum@paik.ac.kr ORCID: https://orcid.org/0000-0002-9274-9371

This is an Open Access article distributed under the terms of the Creative Commons Attribution Non-Commercial License (http://creativecommons.org/ licenses/by-nc/4.0) which permits unrestricted non-commercial use, distribution, and reproduction in any medium, provided the original work is properly cited.

Copyright (C) The Korean Dermatological Association and The Korean Society for Investigative Dermatology 